\title{
Penerapan Jaringan Syaraf Tiruan Untuk Mengukur Regresi Anatara Keaktifan Mahasiswa di Organisasi Dengan Prestasi Akademik Mahasiswa
}

Application of Neural Network to Measure Regression Between Students Organization Activeness With the Student Academic Achievement

\author{
Ayunita Anzani Rahmadyah ${ }^{1}$, T.Sutojo ${ }^{2}$ \\ ${ }^{1,2}$ Jurusan Teknik Informatika, Universitas Dian Nuswantoro Semarang \\ Jl. Imam Bonjol 205-207 Semarang 50131 \\ E-mail : un_zha_nich@yahoo.co.id ${ }^{1}$, tsutojo@gmail.com²
}

\begin{abstract}
Abstrak
Fenomena rendahnya minat dan kesadaran mahasiswa untuk aktif terlibat dalam organisasi kemahasiswaan, terjadi hampir diseluruh kampus di Indonesia. Salah satu faktor yang mempengaruhi hal tersebut adalah adanya asumsi bahwa mahasiswa yang aktif berorganisasi tidak akan bisa meraih prestasi akademis yang memuaskan. Untuk membuktikan kebenaran asumsi tersebut, maka pada penelitian ini diuji hubungan atau regresi antara keaktifan mahasiswa dalam organisasi dengan prestasi akademik mahasiswa, dengan menggunakan jaringan syaraf tiruan Perambatan Balik (JST-PB). Hasil penilitian menunjukkan bahwa keaktifan mahasiswa di organisasi tidak selalu memiliki regresi negatif terhadap peningkatan prestasi mahasiswa. Dari tiga variabel input, dua variabel yaitu jumlah kelompok binaan dan prestasi organisasi menunjukkan regresi positif terhadap variabel output yaitu IPK mahasiswa. Selanjutnya dapat dilakukan penelitian mengenai faktor lain yang dapat mempengaruhi baiknya prestasi akademik mahasiswa.
\end{abstract}

Kata kunci -- Organisasi Kemahasiswaan, Keaktifan Organisasi, Prestasi Akademik, IPK, Regresi, JSTPB

\begin{abstract}
The phenomenon of low interest and awareness of students to get active and involved in student organizations, occurs in almost colleges in Indonesia. One of the factors that affect it is the assumption that the students whose get involved in students organizations will not be able to achieve good point in academic. To prove the truth of this assumption, thus this study is intended to test the relationship or regression between student activity within the organization with student academic achievement using artificial neural networks back propagation. The Results showed that student activity in organizations do not always have a negative regression toward student achievement. From three input variables, two of them, which is number of auxiliaries and achievements organization showed a positive regression with output variable, which is student GPA. Furthermore, research on other factors which may affect the student's good academic performance was recommended.
\end{abstract}

Keywords -- student organizations, organizations activity, academic achievement, GPA, regression, Neural Networks, Back Propagation

\section{PENDAhuluan}

Fenomena rendahnya minat dan kesadaran mahasiswa untuk aktif terlibat dalam organisasi kemahasiswaan, terjadi di hampir seluruh kampus di Indonesia [1]. Virus apatisme yang mengidap mahasiswa bisa diamati dari keengganan mahasiswa terhadap kegiatan-kegiatan positif, seperti 
forum diskusi, komunitas belajar, seni, kerohanian dan lain-lain yang semuanya diwadahi oleh organisasi kemahasiswaan. Padahal, melalui organiasi mahasiswa, dapat diukur sejauh mana seorang mahasiswa dapat memberikan kontribusi kepada masyarakat di sekelilingnya. Selain itu, organisasi mahasiswa juga menyiapkan mahasiswa untuk menghadapi dunia pasca kampus sehingga ia tidak gagap menghadapi dunia nyata, memiliki peta masa depan untuk menyiapkan dirinya sehingga ada langkah-langkah nyata menuju ke sana. Jika saat berorganisasi mahasiswa telah tertanam kebiasaan disiplin dan patuh terhadap segala aturan dan tata karma dalam organisasi, diharapkan tumbuh pula kesadaran semacam itu kelak setelah terjun ke masyarakat, atau memasuki dunia kerja. Hal ini diharapkan dapat menekan angka pengangguran sarjana yang terus meningkat[2]. Tanpa organisasi mahasiswa, mahasiswa tidak akan memiliki sarana yang tepat untuk pembelajaran demokrasi. Mahasiswa yang buta demokrasi, akan tumbuh menjadi bagian masyarakat yang apatis dan acuh tak acuh, sebagaimana terlihat dalam peningkatan jumlah pemilih yang tidak menggunakan hak suaranya di berbagai pemilihan umum baik di tingkat daerah, propinsi maupun nasional di Indonesia [3]. Salah satu hal yang disinyalir sebagai salah satu faktor rendahnya minat mahasiswa terhadap organisasi adalah masih beredarnya sebuah asumsi keliru yaitu mereka yang aktif berorganisasi dikhawatirkan akan mengalami penurunan prestasi akademik sehingga semakin lama waktu yang perlu ditempuh untuk menyelesaikan kuliah. Rendahnya prestasi akademik, dikhawatirkan menyebabkan mahasiswa susah mencari pekerjaan. Inti dari asumsi keliru ini adalah, mahasiswa yang aktif berorganisasi tidak akan bisa meraih prestasi akademis yang memuaskan. Guna memperbaiki dan meluruskan beberapa asusmsi negatif terhadap keaktifan mahasiswa dalam berorganisasi, penulis bermaksud melakukan penelitian untuk mencari hubungan atau regresi antara keaktifan mahasiswa dalam organisasi dengan peningkatan prestasi akademik mahasiswa. Analisis hubungan antara keaktifan mahasiswa dalam organisasi dengan prestasi akademik mahasiswa dilakukan dengan menggunakan metode jaringan syaraf tiruan (JST), dengan pertimbangan JST memiliki kemampuan melakukan komputasi secara paralel dengan cara belajar dari pola-pola yang diajarkan. Dengan kemampuan tersebut, diharapkan JST dapat mengukur regresi terhadap polapola keaktifan mahasiswa dalam sebuah organisasi dengan prestasi akademik aktivis organisasi mahasiswa secara lebih akurat. Hasil penelitian ini diharapkan dapat mengubah paradigma negatif terhadap keaktifan mahasiswa di organisasi mahasiswa sebagai salah satu penyebab turunnya prestasi akademik mahasiswa, sehingga minat mahasiswa untuk aktif dalam kegiatan berorganisasi meningkat, dan tujuan organisasi untuk membentuk sikap dan mental mahasiswa sebagai seorang cendekiawan yang bermoral, visioner dan memiliki kesadaran penuh sebagai bagian dari sebuah bangsa dapat tercapai. Penelitian ini mengacu pada penelitian sebelumnya yaitu Penerapan Jaringan Syaraf Tiruan Untuk Mengukur Tingkat Korelasi antara NEM dengan IPK Kelulusan Mahasiswa [4].

\section{METODE PENELITIAN}

Secara umum, tahapan penelitian dengan menggunakan aplikasi jaringan syaraf tiruan umpan-maju perambatan-balik (JST-PB) seperti ditunjukkan pada Gambar 1. 


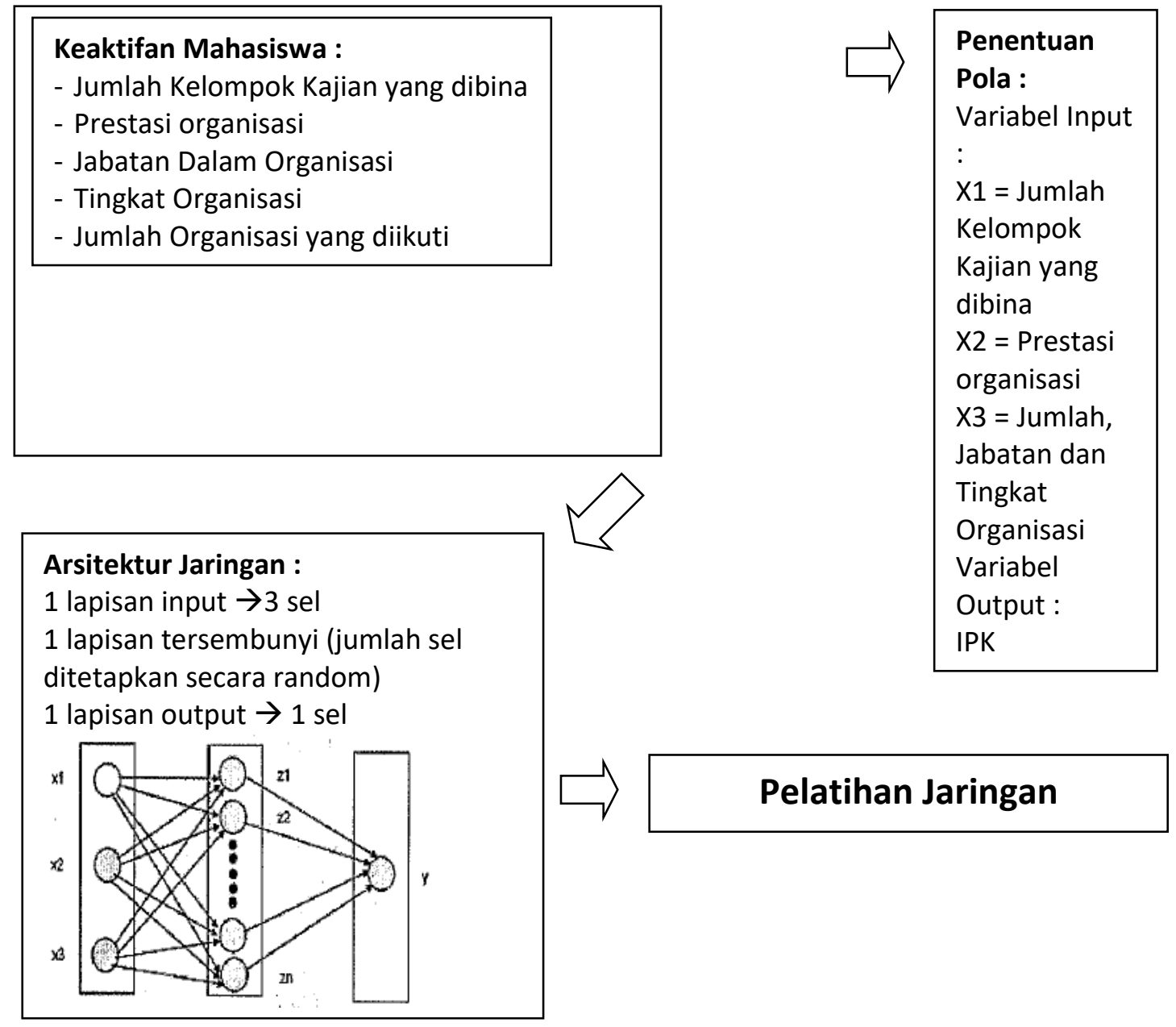

Gambar 1. Tahapan Pengembangan Aplikasi JST-PB untuk megukur Regresi Keaktifan Mahasiswa di Organisasi Mahasiswa dengan Prestasi Akademik Mahasiswa

Pada penelitian ini digunakan metode JST-PB dengan pertimbangan metode ini sangat baik dalam menangani masalah pengenalan pola-pola kompleks dan non-linier [4].

\subsection{Objek Penelitian}

Karakteristik objek dalam penelitian ini adalah aktivis organisasi mahasiswa di Indonesia yang tergabung dalam organisasi Masyarakat Ilmuwan dan Teknolog Indonesia Cluster Mahasiswa (MITI Mahasiswa), dan berasal dari 36 Kampus di Indonesia yang merupakan mahasiswa semester 2 - 8 dengan IPK diatas 2.75, dan atau membina kelokpok kajian keislaman, dan atau memiliki prestasi organisasi, dan atau aktif dalam organisasi mahasiswa. Objek penelitian merupakan peserta ajang MITI Awards yaitu penghargaan terhadap mahasiswa yang memiliki prestasi akademik dan organisasi.

Besar sampel dalam penelitian ini sejumlah 243 mahasiswa anggota MITI Mahasiswa. Hal ini disebabkan karena penggunaan sampel yang besar dalam penelitian dianggap akan menghasilkan perhitungan statistik yang lebih akurat daripada sampel dalam jumlah kecil. Kerlinger dan lee (2000) menyarankan sebanyak 30 sampel sebagai jumlah minimal dalam penelitian [5]. Jumlah data yang akan dilatihkan pada jaringan sebanyak 243 data. 


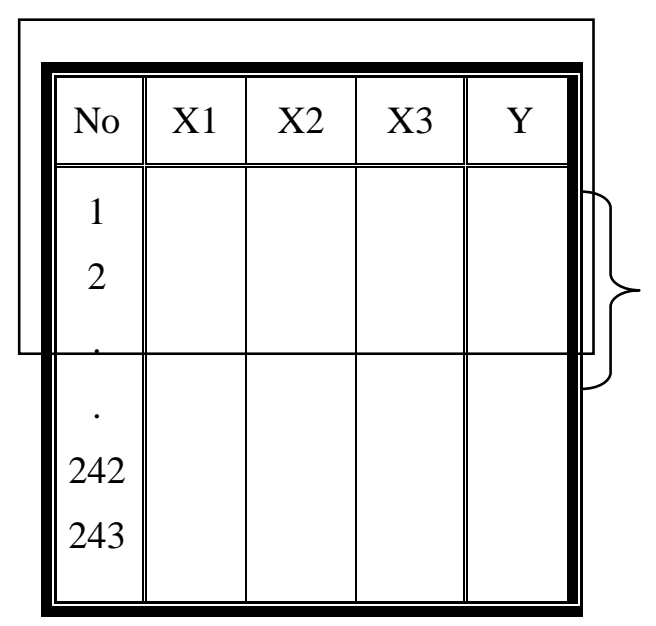

Gambar 2. Data yang digunakan untuk pelatihan JST

\subsection{Metode Pengumpulan Data}

Pengumpulan data dilakukan bersamaan dengan kegiatan MITI Awards. Dari kuesioner peserta ajang MITI Awards, diambil beberapa variable yang dapat mengindikasikan keaktifan mahasiswa dalam organisasi dan prestasi akademik mahasiswa. Data-data yang digunakan dalam penelitian ini kemudian mengambil variabel input berupa jumlah kelompok kajian yang dimiliki mahasiswa, jumlah organisasi yang diikuti mahasiswa tersebut, tingkatan organisasi dan prestasi keorganisasian mahasiswa. Sedangkan output berupa Indeks Prestasi Komulatif mahasiswa. Data yang semula berupa form kemudian di normalisasi sehingga diperoleh angka untuk kemudian dijadikan variabel input JST.

\subsection{Perancangan Arsitektur JST Propagasi Balik}

Arsitektur JST yang dipergunakan di sini adalah propagasi balik dengan cacah input tiga node, sebuah hidden layer dengan cacah node ditentukan secara acak, dan output dengan cacah node satu. Seluruh link synaptic terhubung penuh (fully connected), dengan fungsi aktivasi bipolar sigmoid. Untuk meniadakan threshold dalam perhitungan, setiap lapisan diberikan node tambahan dengan nilai aktivasi selalu 1 , dan bobot synaptic sama dengan nilai threshold node tempat ia terhubung. Skema JST sebagai berikut :

Skema JST sebagai berikut :

1. Satu lapisan masukan yang terdiri atas 3 unit sel

2. Satu lapisan tersembunyi dengan jumlah unit sel yang ditentukan secara acak

3. Satu lapisan keluaran berjumlah 1 unit sel 


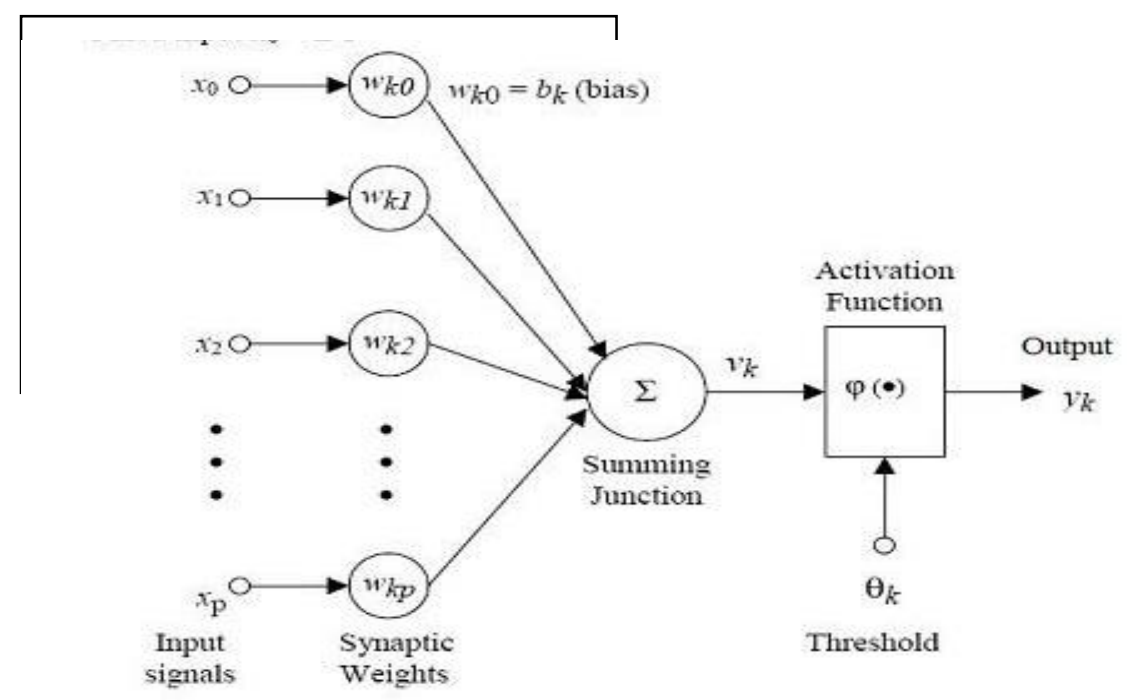

Gambar 3. Arsitektur JST-PB untuk megukur regresi

Keaktifan Mahasiswa di Organisasi Mahasiswa dengan Prestasi Akademik Mahasiswa

\subsection{Perancangan Pelatihan Jaringan}

Pelatihan dilakukan dengan menggunakan perangkat lunak (software) Matlab R2008a yang telah menyediakan fungsi-fungsi pelatihan dan pengujian pada jaringan syaraf tiruan dengan algoritma perambatan galat mundur (backpropagation). Proses pelatihan dilakukan untuk mencari persamaan terbaik dengan cara melakukan pengukuran bobot dan bias secara berulang. Pengisian data latihan secara manual adalah dengan satu persatu memasukkan data secara berurut nomor 1 sampai dengan 243. Hasil pengukuran bobot dan bias tersebut kemudian disimpan, untuk selanjutnya dipilih persamaan yang menunjukkan angka paling sering muncul dan paling stabil atau tidak memiliki perbedaan yang terlalu jauh.

\section{HASIL DAN PEMBAHASAN}

\subsection{Pelatihan JST}

Pelatihan Jaringan dilakukan dengan menggunakan program matlab R2008a. Data dilatihkan dengan dipengaruhi oleh model algoritma jaringan yang digunakan, jumlah lapisan tersembunyi, dan fungsi aktivasi. Pelatihan Jaringan menggunakan konfigurasi JST-PB sebagai berikut.

Jaringan Back Propagation, disimpan dlm variabel net,

Jumlah sel lapisan tersembunyi $\quad: \quad 1$

Iterasi

1000

Konstanta Belajar $\quad: \quad 0.5$

Besar Galat $\quad: \quad 0.7$

Jumlah input sembarang 
Output Jaringan menggunakan fungsi aktivasi Linier 'purelin',

Pelatihan menggunakan Gradient descent with momentum 'traingdm'

Jumlah sel lapisan terembunyi atau hidden layer harus 1, agar persamaan jaringan yang dihasilkan linier yaitu $\mathrm{aX} 1+\mathrm{bX} 2+\mathrm{cX} 3+$ bias $=\mathrm{Y}$. Jika jumlah hidden layer lebih dari 1 , maka persamaan jaringan yang dihasilkan bukan merupakan persamaan linier.

Jumlah iterasi yang digunakan dalam pelatihan adalah 1000 iterasi. Pada dasarnya, semakin banyak jumlah iterasi, maka semakin akurat bobot pelatihan yang dihasilkan. Namun, dengan semakin banyaknya jumlah iterasi, maka proses kerja jaringan juga semakin lambat. Berikut data percobaan pelatihan jaringan dengan jumlah iterasi yang berbeda dan waktu yang diperlukan jaringan untuk menghasilkan data pelatihan.

\subsection{Hasil Pelatihan JST}

Dari pelatihan jaringan secara berulang dengan konfigurasi jaringan JST-PB didapat hasil persamaan sebagai berikut.

Tabel 1: Bobot masing-masing Variabel

Hasil Pelatihan JST

\begin{tabular}{|r|r|r|r|r|}
\hline No & $\mathrm{X} 1$ & $\mathrm{X} 2$ & $\mathrm{X} 3$ & Bias \\
\hline 1 & 0.0231 & 0.0005 & -0.0002 & 0.0316 \\
\hline 2 & 0.0232 & 0.0005 & -0.0002 & 0.0315 \\
\hline 3 & 0.0231 & 0.0005 & -0.0002 & 0.0315 \\
\hline 4 & 0.0231 & 0.0005 & -0.0002 & 0.0315 \\
\hline 5 & 0.0232 & 0.0005 & -0.0002 & 0.0315 \\
\hline 6 & 0.0231 & 0.0005 & -0.0002 & 0.0315 \\
\hline 7 & 0.0231 & 0.0005 & -0.0002 & 0.0315 \\
\hline 8 & 0.0231 & 0.0005 & -0.0002 & 0.0315 \\
\hline 9 & 0.0232 & 0.0005 & -0.0002 & 0.0315 \\
\hline 10 & 0.0232 & 0.0005 & -0.0002 & 0.0315 \\
\hline 11 & 0.0232 & 0.0005 & -0.0002 & 0.0315 \\
\hline 12 & 0.0231 & 0.0005 & -0.0002 & 0.0315 \\
\hline 13 & 0.0232 & 0.0005 & -0.0002 & 0.0315 \\
\hline 14 & 0.0232 & 0.0005 & -0.0002 & 0.0315 \\
\hline 15 & 0.0231 & 0.0005 & -0.0002 & 0.0316 \\
\hline 16 & 0.0232 & 0.0005 & -0.0002 & 0.0315 \\
\hline 17 & 0.0231 & 0.0005 & -0.0002 & 0.0315 \\
\hline 18 & 0.0231 & 0.0005 & -0.0002 & 0.0315 \\
\hline 19 & 0.0233 & 0.0005 & -0.0002 & 0.0315 \\
\hline 20 & 0.0231 & 0.0005 & -0.0002 & 0.0315 \\
\hline 21 & 0.0231 & 0.0005 & -0.0002 & 0.0315 \\
\hline 22 & 0.0232 & 0.0005 & -0.0002 & 0.0315 \\
\hline 23 & 0.0231 & 0.0005 & -0.0002 & 0.0316 \\
\hline
\end{tabular}




\begin{tabular}{|l|lll|l|}
\hline 24 & 0.0232 & 0.0005 & -0.0002 & 0.0315 \\
\hline 25 & 0.0232 & 0.0005 & -0.0002 & 0.0315 \\
\hline 26 & 0.0232 & 0.0005 & -0.0002 & 0.0315 \\
\hline 27 & 0.0126 & 0.0007 & -0.0006 & 0.0327 \\
\hline 28 & 0.0232 & 0.0005 & -0.0002 & 0.0315 \\
\hline 29 & 0.0232 & 0.0005 & -0.0002 & 0.0315 \\
\hline 30 & 0.0232 & 0.0005 & -0.0002 & 0.0315 \\
\hline
\end{tabular}

Dari hasil pelatihan jaringan tersebut, jika data diurutkan berdasarkan persamaan yang muncul, maka akan diperoleh data sebagai berikut.

Tabel 2: Persamaan Hasil Pelatihan JST dan Jumlah Kemunculannya.

\begin{tabular}{|r|r|r|r|l|c|}
\hline No & $\mathrm{X} 1$ & $\mathrm{X} 2$ & $\mathrm{X} 3$ & Bias & Jumlah Kemunculan \\
\hline 1 & 0.0231 & 0.0005 & -0.0002 & 0.0316 & 3 \\
\hline 2 & 0.0232 & 0.0005 & -0.0002 & 0.0315 & 15 \\
\hline 3 & 0.0231 & 0.0005 & -0.0002 & 0.0315 & 10 \\
\hline 4 & 0.0233 & 0.0005 & -0.0002 & 0.0315 & 1 \\
\hline 5 & 0.0126 & 0.0007 & -0.0006 & 0.0327 & 1 \\
\hline
\end{tabular}

Berdasarkan data pada tabel 2, maka persamaan yang akan dianalisa dalam penelitian ini adalah persamaan yang kedua yaitu:

$0.0232 \mathrm{X} 1+0.0005 \mathrm{X} 2-0.0002 \mathrm{X} 3+0,0315=\mathrm{Y}$

Persamaan 4-1 menunjukkan bahwa bobot X1 positif, X2 positif dan X3 negatif.

\subsection{Analisa Hasil Pelatihan JST}

Hasil Pelatihan menunjukkan adanya regresi positif dari variabel X1 yaitu jumlah kelompok binaan, dan variabel X2 yaitu Prestasi Organisasi, terhadap variabel Y atau IPK. Sedangkan variabel X3 yaitu Jumlah organisasi yang diikuti, memiliki regresi negatif terhadap variabel Y. Bila dijabarkan lebih lanjut, korelasi positif antara variabel X1 yaitu jumlah binaan dan variabel Y, yaitu IPK, memiliki arti makin banyak jumlah binaan, maka makin tinggi IPK yang dapat diraih mahasiswa. Hal ini dapat disebabkan karena dalam membina dan mengelola sebuah kelompok kajian, seorang mahasiswa dituntut untuk berwawasan luas. Selain itu, mahasiswa selaku pembina secara tidak langsung memiliki kewajiban untuk menjadi teladan yang baik bagi kelompok binaanya. Oleh karena itu, ketika membina sebuah kelompok kajian, seorang mahasiswa dengan sendirinya akan termotivasi untuk menjadi teladan yang baik dan memiliki pengetahuan yang lebih luas dibanding mahasiswa lain yang dibinanya. Kualitas seorang mahasiswa dalam kedua hal tersebut dapat dibuktikan dari berapa IPK yang mampu diraih oleh mahasiswa yang membina kelompok kajian. Jika seorang pembina ternyata memiliki IPK yang lebih rendah daripada mahasiswa binaanya, maka wibawa dan pamor mahasiswa yang membina tersebut akan jatuh dihadapan mahasiswa yang dibinanya, sehingga tidak akan ada lagi mahasiswa yang tertarik untuk mengikuti pembinaan yang merupakan program dari aktivis organisasi yang bersangkutan. 
Demikian juga dengan variabel X2 yaitu prestasi organisasi dan variabel Y, yaitu IPK, memiliki arti makin banyak prestasi organisasi yang diraih mahasiswa, maka makin tinggi juga IPK yang dapat diraih mahasiswa. Hal ini dapat disebabkan karena seorang yang telah menikmati sebuah prestasi dalam suatu hal, maka ia akan cenderung tidak puas hanya dengan prestasi tersebut, dan berusaha terus mengejar prestasi dibidang yang lain. Maka seorang mahasiswa yang memiliki prestasi dalam sebuah organisasi, umumnya juga akan mengimbangi prestasi organisasi dengan prestasi akademik. Dalam hal ini, prestasi akademik ditunjukkan dengan nilai IPK yang tinggi. Makin baik IPK seorang mahasiswa, maka dapat dikatakan makin baik pula prestasi akademiknya. Salah satu point penting yang menunjang kualitas elemen pada variabel X1 dan X2 adalah pengelolaan waktu yang baik. Ketika seseorang memiliki satu kelompok binaan, maka ia akan berusaha mengelola waktunya sedemikian rupa sehingga kegiatanya membina dalam organisasi dan prestasi akademik atau IPK mahasiswa tersebut, keduanya berhasil dengan baik.

Demikian juga dengan seseorang yang prestatif, hampir dipastikan memiliki manajemen waktu yang baik pula, karena tanpa hal tersebut ia tidak akan bisa membagi waktu antara belajar dan kegiatan organisasinya dengan baik.

Hal ini berbeda dengan variabel X3 yaitu jumlah organisasi yang diikuti. Jika hanya dengan aktif berorganisasi saja tanpa adanya keterikatan untuk menjadi teladan ataupun keinginan untuk mengejar prestasi, maka mahasiswa akan cenderung memilih satu dari dua hal yang disenanginya, aktivitas akademik, atau aktivitas organisasi. Seorang pemilih tentunya akan mengambil satu pilihan, dan meninggalkan pilihan lainya, sehingga tanpa adanya tanggung jawab untuk menjadikan keduanya baik, seseorang yang hanya aktif saja dalam berorganisasi, hanya senang berorganisasi dan mudah bosan dalam perkuliahan akademik, maka prestasi akademik atau IPK yang dimiliki akan semakin menurun, justru ketika organisasi yang diikutinya semakin banyak. Begitu juga ketika dalam berorganisasi seorang mahasiswa hanya mementingkan kuantitas, banyaknya atau beragamnya kegiatan yang diikuti maka kualitas akademik mahasiswa tersebut akan berbanding terbalik dengan kuantitas organisasi yang diikuti.

\section{KESIMPULAN}

Keaktifan mahasiswa di organisasi tidak selalu memiliki regresi negatif terhadap peningkatan prestasi mahasiswa, sebagaiamana dikhawairkan oleh orang tua murid maupun mahasiswa. Dari tiga variabel input yang diinputkan pada jaringan, dua variabel yaitu jumlah kelompok binaan dan prestasi organisasi menunjukkan regresi positif terhadap variabel output yaitu IPK mahasiswa. Hasil penelitrian tersebut diharapkan dapat meningkatkan minat mahasiswa terhadap organisasi karena kekhawatiran mahasiswa, dan juga orang tua mahasiswa tentang aktivitas organisasi yang menyebabkan penurunan prestasi akademik tidak sepenuhnya terbukti.

\section{SARAN}

Dalam penelitian ini hanya dua faktor dalam berorganisasi yang diketahui memiliki pengaruh positif terhadap peningkatan prestasi akademik mahasiswa. Bobot hasil penelitian juga masih menunjukkan angka yang yang sangat kecil, yang berarti hubungan masing-masing variabel input dan variabel output sangat kecil. Responden yang digunakan dalam penelitian ini ada pada range IPK 2.92 dan 4, dengan lingkup daerah seluruh Indonesia. Berdasarkan beberapa fakta diatas, maka beberapa saran yang dapat digunakan pada penelitian selanjutny diantaranya adalah dengan mencari faktor lain dalam berorganisasi yang kemungkinan memiliki pengaruh 
positif terhadap peningkatan prestasi akademik mahasiswa, misalnya jenis organisasi, apakah minat bakat, kerohanian atau penalaran. Faktor lain tersebut kemudian diuji bobotnya untuk mengetahui sejauh mana hubungannya terhadap prestasi akademik mahasiswa.

Penelitian selanjutnya juga dapat dilakukan dengan memperkecil lingkup daerah dengan range IPK antara 0-4.Selain itu, peneliti juga memberikan saran praktis bagi pelaku organisasi untuk dapat meningkatkan kualitas prestasi akademik, yaitu dengan training management waktu bagi calon pengurus organisasi, juga forum akademik untuk memfasilitasi para aktifis organisasi dalam menyelesaikan tugas-tugas akademiknya secara bersama.

\section{DAFTAR PUSTAKA}

[1] http://kampus.okezone.com/read/2012/08/02/95/672169/mahasiswa-baru-di-tengah-kepunganapatisme, diakses tanggal 18 November 2012.

[2] http://www.tempo.co/read/news/2012/04/13/173396869/Satu-Juta-Intelektual-di-IndonesiaMenganggur, diakses tanggal 18 November 2012.

[3] http://isjd.pdii.lipi.go.id/admin/jurnal/61082132_1829-8001.pdf, diakses tanggal 27 November 2012.

[4] Nuraeni, Yeni. (2009). Penerapan Jaringan Syaraf Tiruan Untuk Mengukur Tingkat Korelasi antara NEM dengan IPK Kelulusan Mahasiswa, Jurnal Telkomnika Vol. 7, No.3, Desember, 195-200

[5] Kerlinger, F.N. and Lee, H.B. (2000). Foundations of Behavioral Research. Orlando: Harcourt College Publishers. 